Play Streets: Women, Children and the Problem of Urban Traffic, 1930 1970.

Krista Cowman, University of Lincoln.

Wordcount: 11, 681 words including footnotes excluding abstract

8,956 words excluding footnotes and abstract 
Play Streets: Women, Children and the Problem of Urban Traffic, 1930 1970.

Abstract: This article explores women's participation in campaigns for urban play streets in England c.1930 - 1970. Concentrating on activities in 'traditional' terraced streets, it argues that working-class street sociability was strongly connected to children's play and that rising levels of traffic were beginning to threaten this before WW2, feeding growing anxieties over the high rate of road accidents to children. One response to this from the 1930s was a series of local experiments aimed at separating traffic from children (a radical alternative to the more usual response of keeping children away from traffic) through the creation of 'play streets', closed to traffic for much of the day. The idea was taken up by national government and became popular in post-war decades, often due to the efforts of local women to defend the public life of their communities. The growing controversy over the introduction and maintenance of play streets from the 1960s shows women struggling to maintain traditional street sociability against the gathering power of business interests and rising car ownership in the period.

Key words: play streets; urban traffic; women; street sociability; gendered activism; cars; play; children 


\section{Play Streets: Women, Children and the Problem of Urban Traffic, 1930 - 1970.1}

Sometime in the afternoon of 10 October 1956 a car passing through Hardwick Street in Liverpool collided with two-year old Jennifer Jones, seriously injuring her foot. The day before another girl, Susan Oliver, needed stitches when a car struck her bringing the total of recent car accidents to children on Hardwick Street to nine. Local mothers decided that something had to be done. After an impromptu street meeting they barricaded the street with dustbins, prams and their own bodies, calling for it to become a play street, closed to traffic during the day. ${ }^{2}$

The mothers' attempt to protect street play reflects its importance to postwar working-class childhood. Outdoor play permeated representations of working-class life in this era, for example in the photographs of Bill Brandt, Roger Mayne and Nigel Henderson, whose work often featured children playing. ${ }^{3}$ At the time, as Colin Ward observed, the images were placed paradoxically in texts describing urban decay where the 'words spell deprivation, but the pictures spell joy', but their subsequent reproduction on covers of memoirs of post-war urban childhood aimed at a popular nostalgia market confirms Ward's optimistic reading. ${ }^{4}$ Popular histories of post-war childhood are equally positive about street play. Paul Feeney's 1950s Childhood was

a time when every street seemed to be full of children...streets

were considered safe places for children to be left to play

unaccompanied. Car ownership was still very low and most

vehicles kept to the main roads. ${ }^{5}$

Recent political analysis has continued to associate street play with an absence of cars. In 2003, Estelle Morris (born in 1952) explained how in her childhood, children would

play in the streets but cannot do so any more; looking around the Chamber, I see that most hon. Members are of a similar age and probably did play in the street. That has changed...there is no going back to the days when back alleys were always safe, when streets did not have cars on them. ${ }^{6}$

\footnotetext{
1 Particular thanks to Stephen Brooke, Christine Grandy and Simon Gunn for their comments on earlier seminar and conference paper versions of this article.

${ }^{2}$ Liverpool Echo, 5, 13 October 1956.

${ }^{3}$ Stephen Brooke, 'Revisiting Southam Street: Class, generation, gender and race in the photography of Roger Mayne', Journal of British Studies 53, 2 (2014), 453-496; Joe Moran, 'Imagining the street in post-war Britain', Urban History 39, 1 (2012), 166-186; Matthew Thomson, Lost Freedom: The Landscape of the Child in the British Post-War Settlement (Oxford, 2013), 21-46; Ken Worpole, 'Universal conditions: modern childhood' in J. Pugh (ed), What is Radical Politics Today? (Basingstoke, 2009), 192-3.

${ }^{4}$ Colin Ward, The Child in the City (London, 1978), 210. J. A. D. Blaikie, 'Photography, childhood and urban poverty: remembering the forgotten Gorbals', Visual Culture in Britain, 7, 1 (2006), 4768 similarly notes the juxtaposition of poverty and play.

5 Paul Feeney, A 1950s Childhood (Stroud, 2009), 12.

${ }^{6}$ Hansard, HC, vol. 412, cc .223-41 (4 November 2003).
} 
Other sources reveal a more complex view of street play in the post-war decades. As the examples above suggest, concern originated in pre-war discussions about urban traffic. ${ }^{7}$ A gradual but steady rise in both motor transport and pedestrian injuries and fatalities from the late 1920s provoked fierce debate over the appropriate use of urban streets. Who should be in the streets, at what time, and for what purpose, became important questions for their residents and for local and national government. Some saw the social functionsplay, or chatting to neighbours - of urban sidestreets as incompatible with a growing belief that the unimpeded movement of cars was essential to the effective functioning of the modern city. ${ }^{8}$ Others, less concerned with automobility or car ownership, considered cars as unwelcome intruders on sidestreets, which they sought to defend as a site of sociability.

The Hardwick Street demonstrations thus offer an important entrance into debates on the purpose of sidestreets in post-war England, signalling just what was at stake in attempting to protect social and play spaces in urban environments. They also provide a different angle on women's political activity in post-war Britain. That women were at the heart of efforts to repel the rise of traffic on urban sidestreets suggests an important dimension to women's political activism that has been largely overlooked in the immediate post-war era. Since the 1990s, historians of British women's politics have been critical of the implications of the 'wave' metaphor that suggested a lull in political engagement between the end of the suffrage movement in the 1920s and the development of a distinctive British Women's Liberation Movement (WLM) in the late 1960s. ${ }^{9}$ More recently work by Catriona Beaumont and others has encouraged a shift away from the more traditional sites of political parties to consider women's collective activities in a broad range of organisations - Mother's Unions, Townswomen's Guilds and Women's Institutes - which, while by no means feminist, became key locations for the development of women's politics in the inter and post-war decades. ${ }^{10}$ These studies have been invaluable in familiarising us with the diversity of what Beaumont persuasively describes as a 'women's movement' in inter and post-war Britain, but they remain rooted in an understanding of politics where local activity connects to broader national - or transnational - campaigns, or wider 'social movements'.11

\footnotetext{
7 For concerns see William Plowden, The Motor Car and Politics 1896-1970 (London 1971); Colin Pooley \& Jean Turnbull, 'Commuting, transport and urban form: Manchester and Glasgow in the mid-twentieth century', Urban History 27, 3 (2000), 360-383; Joe Moran, 'Crossing the road in Britain, 1931-1976', The Historical Journal 49, 2 (2006), 477-496.

8 For planners and engineers' views see John Beckman, 'Automobility: a social problem and theoretical concept', Environment and Planning D: Society and Space 19 (2001) 593-607.

${ }^{9}$ Early critiques include Johanna Alberti, Beyond Suffrage, (London, 1989); Harold Smith (ed) British Feminism in the Twentieth Century (Aldershot, 1990).

${ }^{10}$ Catriona Beaumont, Housewives and Citizens: Domesticity and the Women's Movement in England, 1928-1964 (Manchester, 2013). Other work includes: Maggie Andrews, The Acceptable Face of Feminism (London, 1997); P. Thane 'Women and political participation in England, 19181870 in Esther Breitenbach and Pat Thane (eds.) Women and Citizenship in Britain and Ireland in the Twentieth Century: What Difference did the Vote Make? (London, 2010).

11 Beaumont, op. cit., 3
} 
Feminist scholarship in other fields has been more attentive to the range and forms of gendered political activism beyond organisations and attempted to integrate women's everyday experiences into accounts of community activism and politics regardless of whether these connected to national movements or not. ${ }^{12}$ Outside the formal structures of party branches or council chambers are many instances of women displaying what the feminist economic geographers J. K. Gibson-Graham term 'unwitting involvement' in collective community politics, for example community gardening or cooking for communal social events. ${ }^{13} \mathrm{John}$ Horton and Peter Krafti termed these female practices 'implicit activisms,' 'smallscale, personal quotidian' activities, which nonetheless should be read as a gendered politicking. ${ }^{14}$ Much implicit activism rests on women's identity as mothers or carers, undertaken on behalf of a community's rather than a family's children. ${ }^{15}$ The ubiquity of such everyday practices can render them difficult for the historian to identify. Nevertheless there are instances - such as the Hardwick Street protests - where an element of spectacle attaches to them, enabling closer examination of an example of less formal political activism located within the commonplace landscape of women's lives.

The timeframe of this article covers the 1930s to the 1960s, identified by Pooley and Turnbull as a period of 'unprecedented change in urban transport' in Britain. ${ }^{16}$ It suggests that while the continued importance of public street sociability to children and women post-war was recognised through national and local government's roll-out of its play streets scheme from 1938, this became contested throughout the 1950s and 1960s by other interest groups whose priority was business and a related management of urban traffic flow. This divided outlook on suitable play areas resulted in post-war conflict as workingclass women, struggling to maintain traditional street sociability against the gathering power of business interests and car-focussed affluence, combined in locally-based forms of activism in defence of their families and communities.

\section{The 'problem' of urban street play}

Recent histories of post-war working-class communities have paid close attention to their street life. ${ }^{17}$ Despite the impact of widespread slum clearance and redevelopment, the 'traditional' terraced street persisted throughout the 1950s and 60s, when investigations of urban working-class life found it 'an

\footnotetext{
${ }^{12}$ For a useful summary of some of the key literature on this theme see Eleanor Jupp, 'Rethinking local activism: "cultivating the capacities" of neighborhood organising', Urban Studies 49, 14 (2012) 3027-44, especially 3031-2.

13 J.K. Gibson-Graham 'An ethics of the local', Rethinking Marxism 15, (2003) 49-74, 65.

14 John Horton and Peter Krafti, 'Small acts, kind words and "not too much fuss": Implicit activisms', Emotion, Space and Society 2 (2009) 14-23, 14.

${ }^{15}$ For an early example of this see C. T. Gilkes, "'Holding back the ocean with a Broom: Black women and community work', in L. Rogers-Rose (ed) The Black Woman (Beverley Hills, 1980) 217-31.

16 Pooley and Turnbull, op.cit.,5.

17 Examples include Robert Colls, 'When we lived in communities' in Robert Colls \& Richard Roger, (eds), Cities of Ideas: Civil Society and Urban Governance in Britain, 1800 - 2000 (Aldershot, 2004), 283-307; David Kynaston, Family Britain 1951 - 1957 (London, 2009), 221-46; Alison Ravetz, Council Housing and Culture: The History of a Social Experiment (London 2009), 221-46; Selina Todd, The People: The Rise and Fall of the Working Class 1910-2010 (London, 2014).
} 
important meeting place, especially for housewives.'18 Whereas informal indoor socialising such as the act of 'popping in' to a neighbour's house held complex meanings, the street offered a more democratic site for chance encounters and gossip. ${ }^{19}$ Women's street sociability was bound up with the street's continued function as a play space. Observers of playing habits in mid-twentieth century Britain found that children in poorer urban neighbourhoods played near to their own houses, particularly in the pre-school years when they were 'not permitted to stray from the immediate vicinity of their homes.' ${ }^{20}$ Children's outdoor play facilitated women's sociability and encouraged their use of the street. ${ }^{21}$ One study of Sheffield in 1954 noted that much social contact between female neighbours was initiated via their 'small children who....play near their own homes.'22 Mothers keeping younger children within sight or 'calling distance' were a common presence on the doorsteps of terraced streets 'tak[ing] a break, arms folded...watching the children play.'23 Supervision was a collective endeavour as Shirley Evans remembered from her 1950s Liverpool childhood where 'the neighbours would come out and watch us. They would sit on the low walls between the houses watching us play.'24 This pattern was replicated on the continent, for example in Stina Sandels' influential 1968 report into children and traffic which found that Swedish city 'children prefer to play... right beside their own door.'25

Not everyone was comfortable with allowing street play, however. Finding appropriate playspace for working-class urban children had preoccupied social reformers since the nineteenth century. ${ }^{26}$ Concerns over street play's safety and propriety grew during the twentieth century. At the end of World War One, the Ministry of Reconstruction's Women's Housing Sub-Committee called for designated play provision in new housing schemes, lamenting the fact that working-class children played 'on the street with all its dangers and shortcomings.' ${ }^{27}$ Inter-war debates about the causes of juvenile delinquency

\footnotetext{
${ }^{18}$ Josephine Klein, Samples from English Cultures Volume 1 (London, 1965), 141.

${ }^{19}$ Leo Kuper, 'Blueprint for living together' in Leo Kuper (ed), Living in Towns (London, 1953),

51. For gossip see Melanie Tebbutt, Women's Talk? A Social History of 'Gossip' in Working-Class

Neighbourhoods (Aldershot, 1995). The street as a neutral territory appears in Peter Townsend, The Family Life of Old People (London, 1957), 122.

20 The National Archives (subsequently TNA) HLG 118/166, Memo from Paddington Police Station, 3 October 1934. See also G. Duncan Mitchell and Thomas Lupton, 'The Liverpool estate' in G. Duncan Mitchell, T. Lupton, Mark W. Hodges and Cyril S. Smith, Neighbourhood and Community (Liverpool, 1954), 58; Kuper, op.cit., 127.

21 On the contemporary importance of outdoor play to women's street sociability see Jupp, op. cit., 3035. Dina Vaiou and Rouli Lykogianni noted similar phenomena in their studies of modern day interactions between working-class women in the Greek neighbourhoods of Petralona and Kypseli. See Dina Vaiou and Rouli Lykogianni, 'Women, neighbourhoods and everyday life.' Urban Studies 43, 4 (2006) 731-743.

${ }^{22}$ Hodges and Smith, 'The Sheffield estate' in Mitchell et. al. op. cit., 115.

${ }^{23}$ C. V. Godfrey, Road Sense for Children (Oxford, 1937), 66. See also Iona and Peter Opie, Children's Games in Street and Playground (Oxford, 1969), 10.

24 Pamela Russell, Liverpool's Children in the 1950s (Stroud, 2012), 35.

25 Stina Sandels, Children in Traffic (London, 1968).

${ }^{26}$ For Victorian approaches see Ellen Ross, Love and Toil (Oxford, 1993); Seth Koven, Slumming (London, 2006); Anna Davin, Growing Up Poor (London, 1996).

27 BPP, Final Report of the Ministry of Reconstruction Advisory Council Women's Housing SubCommittee 1918, (Cd. 9232) paragraph 58. For women's views on housing design see Krista
} 
invoked the negative social consequences of a lack of suitable play space. Indeed, the practice of street play could be a criminal act, a matter of concern to Parliament. Speaking in a debate on urban recreation in 1926, Nancy Astor stated that she knew of 'no more pitiable sight in life than a child which has been arrested for playing in the street.' William Buchanan's contribution to the Juvenile Offenders, Scotland Bill (1925) noted that as 'young people will amuse themselves...in a city like Glasgow where the[y] have no open spaces and no facilities for recreation, [t] hey will amuse themselves in the streets.' 28 Worry about a perceived connection between inadequate play space and delinquent behaviour increased during World War Two when a number of factors - absent service fathers, the growing numbers of women involved in war work and sporadic school closures due to air raids - prompted a rise in unsupervised children in city streets and delinquency rates rose. ${ }^{29}$ Street play continued to criminalise large numbers of children after the war. In 1950, 163 Liverpool children were convicted for this against 130 for wilful damage. ${ }^{30}$

How to react to the sight of working-class children playing on wardamaged streets sharply divided opinion in the post-war decades. Some observers approached this with a sense of what Moran has termed 'anticipatory nostalgia,' a marker of vibrant community life now threatened by redevelopment, others read it as a dangerous symbol of social breakdown. ${ }^{31} \mathrm{John}$ Fowles' pejorative description of 1950s Camden connected the physical decay of its 'peeling, pitted, endlessly dirty houses' to the spectacle of 'children playing in the street,' and some campaigners now sought to remove play from city streets altogether. ${ }^{32}$ Britain's few inter-war playgrounds were mostly in public parks, separated from more populated areas. ${ }^{33}$ In 1946, Lady Allen launched her campaign for 'junk' or 'adventure' playgrounds with an article in Picture Post, applauding a wartime experiment in Emdrup, Copenhagen that she wished to see replicated in Britain. ${ }^{34} \mathrm{~A}$ few adventure playgrounds subsequently opened on

Cowman, 'From the housewife's point of view: female citizenship and the gendered domestic interior in post-first world war Britain, 1918-1928', English Historical Review 130, 543 (2015), 352-383.

${ }^{28}$ Hansard, HC vol. 194 cc. 2129-74 (28 April 1926); HC vol. 209 cc. 1709-15 (29 July 1927).

${ }^{29}$ See, for example, Marie Paneth, Branch Street (London, 1944). For wartime rises see J. H. Bagot, Juvenile Delinquency (London, 1941), 89, 90. For an analysis see the articles by David F. Smith, 'Official responses to juvenile delinquency in Scotland during the Second World War', Twentieth Century British History 18:1 (2007) 78-105; 'Delinquency and welfare in London: 1939-49', The London Journal 38: 1, (2013) 67-87.

30 John Baron Mays, Growing Up in the City (Liverpool, 1954), 78.

31 Moran, 'Imagining', op cit., 169. For negative interpretations of bombsite play see Ben Highmore, 'Playgrounds and bombsites: postwar Britain's ruined landscapes', Cultural Politics 9, 3 (2013), 323-336; Gabriel Moshenska, 'Children in ruins: bombsites as playgrounds in second world war Britain’ in Bjørnar Olsen and Póra Pétursdóttir, (eds), Ruin Memories (London, 2014), 230-249.

32 D. Kynaston Modernity Britain, 1957 - 1959 (London, 2013), 32.

${ }^{33}$ Helen Wolley, Urban Open Spaces (London, 2003), 96-8; A. B. Grove and G. F. Chadwick, 'A play area in high density development', Housing Centre Review 6 (1953), 14-17.

${ }^{34}$ Marjory Allen, 'Why not use our bomb sites like this?' Picture Post, 16 November 1946, 26-29. For the history of British adventure playgrounds see Krista Cowman, 'Open spaces don't pay rates: urban wastelands as junk playgrounds in Britain c.1945-70' in Christoph Bernhardt (ed), Between Planning and Appropriation: Urban Open Spaces in Past and Present (Berlin, 2016); Roy Kozlovsky, 'Adventure playgrounds and post-war reconstruction' in Marta Gutman and Ning de 
bomb sites, set apart from the homes of the children using them. The distance between playground and street was considered an advantage. John Barron Mays who helped establish Liverpool's Rathbone Street Adventure Playground explained how its children needed a 'comparatively spacious area' as 'the streets are the traditional places where they kick a ball, climb lampposts or build their brickbat houses.' 35 Mays believed that separating play from home was most critical in central areas where Liverpool's overall juvenile delinquency rate of one-and-a-half per cent increased 'possibly by as much as thirty times' but where 'there were few, if any...playgrounds...and children have to look outside the home for guidance and recreation.' 36

Some organisations supported ending street play. The National Playing Fields Association (NPFA), formed in 1925 to campaign for space for football and other team games, voiced concern about its effect on children's health in the 1930s, acknowledging that 'although back streets are not now as dirty as they used to be owing to the gradual disappearance of horse traffic, it cannot be said that they are particularly hygienic as playgrounds.'37 NPFA secretary, Sir Lawrence Chubb had other concerns, warning Home Office officials that it was 'better for children's morals to be in playgrounds than in the streets, especially now when there is so much unemployment and they mix in the streets with people whose language and behaviour is generally bad.'38 The post-war NPFA placed greater emphasis on the physical dangers of street play. At its silver jubilee dinner, President Lord Mountbatten spoke of an urgent need for playgrounds 'to keep [children] off the streets and so mitigate the horrifying toll of child life due to street accidents' while Herbert Morrison said that he knew 'from experience about playing...[that] streets are not designed for children.'39 The NPFA then offered grants to fund two urban adventure playgrounds. ${ }^{40}$ Organisations seeking to improve urban play provision continued to raise ethical objections to street play in subsequent decades. In the 1950s the Mother's Union called for separate play spaces to curb 'the present growth of hooliganism.' 41 Women MPs campaigning for wider housing improvements emphasized the link between safe outdoor play and children's social development. Eirene White and Margaret Thatcher both sat on a committee considering the impact of high-rise living on young children in 1962. Its deliberations with other women's organisations concluded that improved play facilities were important in the prevention of delinquency later.' 42

\footnotetext{
Connick-Smith (eds), Designing Modern Childhoods (New Brunswick, 2007); Kozlovsky, 'Urban play: intimate space and postwar subjectivity' in Vitoria Di Palma, Diana Periton and Mariana Lathouri, (eds), Intimate Metropolis (London, 2009), 195-217; Kozlovsky, The Architectures of Childhood (Aldershot, 2013), 46-91; Thomson, op. cit., 142-6.

35 John Barron Mays, Adventure in Play (Liverpool, 1957), 7.

${ }^{36}$ Mays, Growing Up, op., cit., 210.

37 TNA MEPO 2/7803. Draft memo from Lawrence Chubb to Home Office, 17 October 1932.

38 Ibid., Notes of meeting at Home Office, 31 October 1932.

39 The Times, 21 October 1948.

40 Allen, Memoirs, op. cit., 236.

41 The Times, 20 December 1952.

42 TNA HLG 118/166, Notes of meeting, 23 January 1962. See also The Housing Centre, Two to Five in High Flats (London, 1962).
} 
Others, like Mountbatten, were more concerned about how street play exposed children to road traffic accidents. This too had pre-war roots, apparent since the first government road accident statistics appeared in 1926. By the 1930s, as Moran has noted, child deaths (which totalled 14,000 between 1927 and 1937) became 'a particular concern.' ${ }^{43}$ Comparisons were drawn with military losses. The Daily Telegraph labelled the casualties for 1934-5 as 'more murderous than the three years of the South African War' while the Scotland Yard Commissioner and traffic expert Herbert Alker Tripp described pre-war casualties as 'at battle level.'44 Fatal accidents rose during the war, fuelled by the blackout and large numbers of inexperienced young military drivers. ${ }^{45}$ Children were disproportionately at risk as fatalities reached 'crisis proportions' rising from 850 in 1939 to 1231 in 1941.46 In July 1943, the Daily Mail reported that in June, 'for the first time in history, more children than adults died on the roads' in Britain. ${ }^{47}$ Although Bill Luckin and David Sheen categorised the wartime period as 'a continuation and culmination of an era of "slaughter"', peace brought little change. ${ }^{48}$ Anxiety about children's safety grew alongside the number of licensed cars in Britain, which jumped from 3 million to 4.5 million between 1939 and 1950, then doubled to 9 million by 1960.49

Particular class connotations underpinned pre and post-war worries about child casualties. Sean 0'Connell's study of the class and gendering of prewar car ownership developed Plowden's description of the 1930s car as a 'middle-class killer' of pedestrians to suggest a level of class conflict in discussions of road traffic accidents, as car owners were more likely to be middleclass while their pedestrian victims, particularly children, would be workingclass. ${ }^{50}$ John Law's examination of accidents on London's arterial roads confirmed the picture of wealthier motorists 'killing large numbers of very young and elderly cyclists and pedestrians', all poorer than the drivers who ran into them. 51 While some studies of automobility showed cars bringing mid-century upper and middle-class women independence, control over their own mobility and the chance to prove themselves 'competent technological actors,' less affluent women were not similarly advantaged.52 Judy Wajcman's study of post-war women's

\footnotetext{
43 Moran, 'Crossing', op. cit., 479.7

44 Daily Telegraph 4 Jan 1935 cited in Moran, 'Crossing', op. cit., 479; Herbert Alker Tripp, Town Planning and Road Traffic (London 1942), 15.

45 Bill Luckin and David Sheen 'Defining early modern automobility: the road traffic accident crisis in Manchester 1939 - 45', Cultural and Social History 6, 2 (2009), 211-30.

${ }^{46}$ Luckin, 'War on the roads: traffic accidents and social tension in Britain, 1939 - 45', In R.

Cooter \& B. Luckin, eds., Accidents in History (Amsterdam, 1997), 236; RoSPA, Road Accident Statistics, 1938-54 (London, n.d.), 1- 4.

47 Daily Mail, 30 July 1943.

48 Luckin and Sheen, p.212.

${ }^{49}$ Simon Gunn, 'The Buchanan Report, environment and the problem of traffic in 1960s Britain', Twentieth Century British History 22, 4 (2011), 521-542, 523.

50 Plowden, op. cit., 263-285; Sean O'Connell, The Car in British Society: Class Gender and Motoring (Manchester, 1998), 120-22.

${ }^{51}$ John Law, 'Speed and blood on the bypass: the new automobilities of inter-war London', Urban History 39, 3 (2012), 490-509, p.508

52 Georgina Clarsen, Eat My Dust: Early Women Motorists (Baltimore, 2008), 160. Laura Doan, 'Primum Mobile: women and auto/mobility in the era of the Great War', Women: A Cultural Review, 17, 1 (2006), 26-41.
} 
relationship to technology found that many working-class women were 'literally left stranded in...cities designed around the motor car.'53 Cars complicated female sociability as explained in Hannah Gavron's study of housebound working-class mothers which connected their isolation to 'the problem of traffic...[that] makes the kind of street life...of previous generations increasingly rare. ${ }^{54}$ For these mothers and their children, car expansion represented a fundamental attack on their freedom to mix within their communities.

Children's proximity to cars on post-war urban streets had other negative outcomes. Rising car ownership outpaced parking provision in middle-class areas, and kerb-space occupancy in certain London streets rose from $50 \%$ in 1951 to $75 \%$ in 1953.55 The problem spread as car ownership increased - albeit slowly and with regional variations - among working-class families, very few had suitable parking. Approximately three quarters of homes on council estates were garageless. ${ }^{56}$ On-street parking was controversial, as shown by an anonymous St Helen's resident who queried whether those parking in his street 'would...buy furniture if they had no house...to keep it in.'57 Working-class men who owned cars were deeply invested in their vehicles, seeing them as status symbols which brought 'self-confidence' and 'assurance', so the threats of playing children damaging them or teenagers stealing them for 'joy riding' were matters of growing concern. ${ }^{58}$ Youngsters' street sociability became more menacing as in the new Scottish estate of Easterhouse, where 'it wasn't long before children playing football in the streets and teenagers meeting their friends on the corners, came to be seen as something of a nuisance, both to the residents and to the police. 59 Younger teenagers were considered particularly prone to sliding into criminalisation as the lines between outdoor play and sociability and delinquent behaviour blurred and 'activities that are play to them are regarded as delinquency by adults.' 60

One obvious way to reduce damage to cars and accidents to children was to separate children from traffic. Moran's research demonstrates how government and pressure groups used a variety of approaches to reduce child injuries between the 1930s and 1970s by doing just this. ${ }^{61}$ Legislation, including the 1934 Road Traffic Act, brought new requirements for drivers and significant changes to the landscape of city streets including pedestrian crossings (identified

\footnotetext{
53 Judy Wajcman, Feminism Confronts Technology (London, 1991) p.129.

54 Hannah Gavron, The Captive Wife (Harmondsworth, 1966), 61.

55 Plowden, op. cit., 328.

56 Simon Gunn, 'People and the car: the expansion of automobility in urban Britain c.1955-70', Social History, 38,2, (2013), 220-237, 231.

57 Liverpool Echo, 3 October 1956.

58 Ferdynand Zweig, The Worker in an Affluent Society (London, 1961), 107; Kuper, 'Blueprint ', op cit., 73; Louise Jackson and Angela Bartie, 'Children of the city: juvenile justice, property and place in England and Scotland, 1945-60', Economic History Review, 64 (2011), 83-113, 97, 107, 108. See also Ward, The Child, 136.

${ }^{59}$ Gail Armstrong and Mary Wilson 'Delinquency and some aspects of housing' in Colin Ward (ed), Vandalism (London, 1973), 64-84, 76. See also Jackson and Bartie, op. cit., 109.

60 University of Warwick, Allen Papers MSS 121/AP/3/3/1. Lady Allen, 'Suggestions for converting part of the Geraldine Mary Harmsworth Park into a waste materials experimental playground', Jan. 1953.

61 Moran, 'Crossing', op. cit.
} 
by new road markings and 'Belisha' beacons) and school railings. Local and national government sought to enhance new street furniture's effectiveness through education including advertising campaigns, road safety sessions in schools, and kerb drill, devised by the Royal Society for the Prevention of Accidents (RoSPA). ${ }^{62}$ While all these initiatives aimed to reduce accidents to children by keeping them away from cars, some local authorities considered a radically different approach, inspired by a scheme from 1920s New York. Rather than keeping children away from cars, this aimed to separate cars from children, closing certain residential streets to traffic between designated hours 'to provide play spaces in localities where there are no playgrounds.' 63 The closed streets were known as 'play streets'; play, not traffic, was their primary purpose. Their location - in less affluent districts with low levels of residential car ownership showed their main targets were motorists driving through residential urban streets on the way from one part of a city to another. Unlike previous approaches to child safety, play streets started from the assumption that city children had the right to play in the streets where they lived, and that cars, not children, were the main problem.

\section{Introducing Play Streets}

New York's play streets attracted international attention. They were discussed in Parliament. In 1928 the Bishop of Southwark queried whether they might be used in London; the following year Ellen Wilkinson asked if streets 'in crowded areas' could be closed to traffic 'during the Whitsun holidays.' ${ }^{64}$ Although no suitable national legislation existed, local authorities had various powers to close streets if they chose. In 1929 Salford, 'the most densely populated area' outside London, became the first city in England to use these powers to introduce play streets along the New York lines. ${ }^{65}$ Salford's authorities were sufficiently concerned about accident rates to establish a separate Traffic Office as early as 1928 where questions of 'traffic in general and its ancillary problems' received 'the whole-time application of experts.'66 The play street experiment was driven by Salford Chief Constable, Major C. V. Godfrey. Alarmed by a 'yearly increase in street casualties, particularly...to children,' Godfrey requested an analysis of figures. This revealed that 'an enormous number' stemmed from 'children...playing in the streets' which they 'regarded...as their playgrounds' colliding with non-resident drivers who considered them 'as convenient short cuts' even when they had 'no necessity to do so.' ${ }^{\prime} 7$ The Traffic Office, recognising that 'fast-moving traffic and children, whose attention was monopolized by play, had become two dangerous and conflicting elements' requiring segregation, looked to New York to achieve this. Acknowledging that it would be 'impossible' to 'remove the children from the streets' completely they opted to exclude traffic as 'the only logical alternative.' 68 When Salford Watch Committee sanctioned the

\footnotetext{
62 Ibid. See also Godfrey, op. cit.

63 TNA MEPO2/7803. Letter from Philip Hoyt, NYPD to Gilbert Carmichael, New Scotland Yard, 14 November 1932.

64 Daily Mail, 15 Feb 1928; Ministry of Transport Report on Street Accidents to Children in Greater London, London, 1919, p. 16; HC Deb 09 May 1929 vol. 227 c2323.

65 Godfrey, letter, The Times, 8 September 1934.

66 Godfrey, Roadsense, op cit., 22.

${ }^{67}$ Ibid., 64, Godfrey, letter, op. cit.

${ }^{68}$ Godfrey, Roadsense, op. cit., 22, 64 .
} 
closure of 48 streets to traffic in July, the first, Clementson Street, was soon 'filled with children'. ${ }^{69}$ A further 32 streets were added in May 1930 with 22 more in November, halving the number of child fatalities in road accidents by September $1931 .{ }^{70}$ Initial closures were voluntary, but the 1933 Salford Corporation Act enabled compulsory closure. In 1934, Godfrey reported that the experiment had reduced accidents across the city and eliminated them entirely in play streets. ${ }^{71}$ Manchester's Chief Constable commended the arrangements to his Watch Committee in July 1932, noting that local accidents peaked 'during the out-ofschool hours when the children resorted to the streets for their games.'72 Birmingham included similar measures in the Birmingham Corporation Bill (1935) and another scheme was operating in Stoke-on-Trent by 1937.73

Play streets were first considered suitable for provincial cities where traffic was presumed lighter. The 1929 Report on Street Accidents to Children in Greater London mentioned the Bishop of Southwark's advocacy, but concluded the scheme was not 'a practicable [solution] for London.'74 Concern remained over children's accident levels in the capital, and as awareness of successful provincial play streets spread, the Home Office examined their operation. In September 1934 Minister of Transport, Leslie Hore-Belisha, said that three Paddington streets in 'a poor neighbourhood used for play' would be identified to drivers by signs requesting that they slowed down. ${ }^{75}$ In 1935 he announced that six streets in Paddington and Southwark would be closed to cars entirely, and declared himself willing to consider further applications for trials from local authorities the following year. ${ }^{76}$

These early experiments faced some opposition. Motorists resented the attack on their freedom. There were concerns that play streets, like road safety drills for children, represented undue government interference in citizen's lives with overtones of 'Hitlerism' or totalitarianism. ${ }^{77}$ London taxi drivers' journal Green Badge declared that while its drivers would never criticize a scheme intended to help 'those unfortunate children...whose only playground is in the streets' play streets 'may only be the thin end of the wedge' in granting municipal authorities 'certain powers.'78 World land speed record holder Sir Malcolm Campbell wrote an article in the Daily Mail in 1934 illustrated with a photograph of German children in a Spielstrasse, 'one of the streets in Hamburg set aside for children' where 'no traffic is allowed' to suggest that play streets were both alien and sinister. ${ }^{79}$ Motorists' advocates exploited childless residents' anxieties that

\footnotetext{
69 Daily Mail, 29 July 1929.

70 Ibid., 29 September 1931.

71 Godfrey, letter, op. cit.

72 The Times, 22 July 1932

73 TNA ED 31/472 Letter from C A Birtchnell, Ministry of Transport, to H. Ritchie, Board of Education, 16 December 1937.

${ }^{74}$ Ministry of Transport, Report on Street Accidents to Children in London (London, 1929).

75 The Times, 11 September 1934.

${ }^{76}$ Hansard, HC, vol .12 cc. 1852-3 (5 June 1935); HC, vol. 313 c. 1755 (24 June 1936).

77 Moran, 'Crossing', op. cit., 482.

78 TNA MEPO 2/7803, cutting 15 June 1929.

${ }^{79}$ Daily Mail, 16 November 1934.
} 
play streets might attract 'all the children from the neighbouring streets'. ${ }^{80}$ Daily Mail motoring correspondent W. A. McKenzie reported 'an outcry from residents and local householders' against attempts to introduce them to London while Rotherhithe MP Benjamin Smith, a former taxi-driver, claimed that closing streets to traffic in a 'slum area' had forced 'the inhabitants...to put up with the antics of every child from the immediate vicinity.' 81 In Haringey, the local ratepayers' association had asked authorities to reduce noise in their neighbourhood by closing its streets to vehicles but opposed the introduction of play streets, adding that if this was 'the only way we can get [streets] closed to traffic, we would rather have the traffic.' 82 The Home Office feared costs, assuming that extra police would be required to enforce the regulations, supervise the children and 'deal with claims for damages (broken windows, lamp stands etc.).' 83 Even sympathetic observers worried that temporarily transforming streets into playgrounds might lull children into a false sense of security about their safety overall. Barbara Murray from Toynbee Hall was interested in play streets' 'recreative possibilities for slum children' but feared that they might make them 'so used to playing in the roadway...that they will forget themselves in a non-play street.' 84 Similar qualms about state interference with motorists' freedom, the level of nuisance and the impact on broader safety remained audible throughout the lifetime of play streets.

Others, more convinced of the legitimacy of urban street sociability, sought to defend it against the threat of rising traffic. Promoters believed play streets had a key role in allowing children to play on their doorsteps. An interdepartmental committee set up by the Department of Education and Ministry of Transport to inquire into children and road safety in 1935, included 'legislation to enable local authorities to provide play streets' among its recommendations. ${ }^{85}$ Various arguments were advanced to counter the scheme's critics. As play streets kept children close to their homes, it was thought unlikely that they would be overrun by others from neighbouring streets, especially if block closures were implemented. Major Godfrey explained how this worked in Salford where groups of 'streets [were]...closed in such numbers as to accommodate a fair proportion of the juvenile population spread over a representative area,' reducing residents' complaints. ${ }^{86}$ Rather than encouraging delinquency, advocates argued, play streets would keep children from a legal system that criminalized outdoor play. Speaking in their support in Parliament, Wavell Wakefield reported that in 1935 'nearly 2,000 young people were found guilty of playing in the streets' ${ }^{87}$ In play streets, play would no longer be a crime.

\footnotetext{
80 TNA MEPO 2/7803, Letter from Ministry of Transport to Commissioner of Police, 6 August 1935.

${ }^{81}$ Daily Mail, 19 November 1937; Hansard, HC, vol. 39 c. 145-69 (4 March 1936).

82 Daily Mirror, 10 October 1939.

83 TNA MEPO 2/7803, McIver's notes on Home Office Conference, November 1932.

84 Ibid., memo from Mr. Chamberlain, 20 March 1933.

85 The Times, 11 Sept 1934.

${ }^{86}$ Godfrey, Road Sense, op. cit., 68.

${ }^{87}$ Hansard, HC, vol. 330 cc. 770-9 (10 December 1937).
} 
The 1930s thus saw mounting consensus about play streets' necessity in 'congested areas' with no alternative facilities. ${ }^{88}$ The new Minister of Transport Leslie Burgis continued to press for a London-wide scheme, designating one South Marylebone and three Willsden streets as play streets in 1937. ${ }^{89}$ Finally in 1937, Robert Perkins, Conservative MP for Stroud, introduced a Street Playgrounds Bill to Parliament. The bill, which had cross-party support, enabled local authorities to close designated streets to traffic entirely or restrict vehicular access during identified hours. It became law in July 1938 in England and Wales (with a clause enabling similar legislation in Scotland) remaining in force until 1960, when Section 49 of the Road Traffic Act superseded its powers. War interrupted the spread of play streets but there was a slow but steady rise in their post-war numbers. Seventeen local authorities had orders confirmed by 1950; eight in the North West, five in London, two in the North East, and one each in Wales and the South East. Eight more had applications pending. ${ }^{90}$ By 1963 there were 146 orders covering 750 urban streets. ${ }^{91}$

Public discussion of play streets confirmed them as a working-class phenomenon and affirmed the sociability of working-class streets. They were aimed at children with little access to open spaces beyond their own streets. Opening the Bill's second reading, Robert Perkins alluded to parts of 'the industrial North' with slum areas 'so congested that it is practically impossible to provide a proper playground for the children...[who] spend their days playing in the streets. ${ }^{92}$ A post-war report on a plan to extend play streets across Kingstonupon-Hull described their typical situation among 'terrace type houses fronting directly on to the footpaths with little or no garden forecourts...generally...sited in the poorer parts of the town where adequate facilities for playgrounds do not exist.'93 Godfrey's original idea for clustering play streets remained the preferred model. Instructions to local councils following the 1960 Road Traffic Act confirmed this, advising that 'groups of streets should be selected in preference to single streets to preclude the possibility of all the children in the area flocking into one street.'94

How best to identify play streets to children and motorists remained a concern throughout the scheme's active life. During the experimental phase some supporters hoped for significant transformation of designated streets. Godfrey regretted the unaffordability of rubber paving which he felt 'would both reduce the volume of sound and make for a safer playing surface.' He hoped future schemes could be planned into new developments and include 'swings, see-saws, and slides, and even an occasional bench' although he admitted that this would really only be practical in 'a cul-de-sac.' Others cared more about recognition than equipment. The 1938 legislation did little to abate concerns

\footnotetext{
${ }^{88}$ See for example Kathleen Watt, 'Let them play in safety', Daily Mirror, 10 May 1938.

${ }^{89}$ Daily Mail, 5 July 1938.

${ }^{90}$ Hansard, HC, vol. 129 cc. 33W (28 March 1950).

91 Ibid., vol. 689 cc. $14304 \mathrm{~W}$ (10 July 1963).

92 Ibid.,vol. 330 cc. 770-9 (10 December 1937).

93 TNA MT 137/6. Divisional Road Engineer (North Eastern Division) to Ministry of Transport, 2 November 1959.

${ }^{94}$ Ibid., Ministry of Transport Circular no. 787, 12 July 1961.
} 
that play streets might encourage children 'to think that playing in the road is harmless. ${ }^{95}$ Fears grew as the scheme rolled out nationally. Lt. Col. Packard from RoSPA warned the Ministry of Transport that 'some distinctive sign to show children that this is a special street, quite distinct from others', was required. He proposed painting the lamp posts in play streets in a different colour from those in non-play streets, while another member of RoSPA suggested painting either end of the road. ${ }^{96}$ Chelsea Borough Council debated introducing yellow street lamps to its first play streets, while Hore-Belisha considered green kerbstones. ${ }^{97}$ Whether the message was getting through to children was less certain. A survey by Stockport Council's Road Safety Committee in 1950 found that the majority of local children misinterpreted the city's parking signs (a white ' $\mathrm{P}$ ' on a blue background') thinking that the ' $\mathrm{P}$ ' stood for play street. ${ }^{98}$

Coloured paint was not adopted. Play streets were identified by entry signs aimed at motorists rather than children. Various wording was at tried; signs for Manchester's first play streets read 'City of Manchester Play Street', those in Salford informed motorists that the street was 'Closed to mechanically propelled vehicles and pedal cycles from sunrise to sunset except vehicles going to and from premises on the street.' 99 Signs at the entrance to Waverly Terrace, Paddington, read 'To drivers - please do not use this street during school hours' while those at the ends of Paignton and Woodchester Streets read 'To Drivers: No Through Traffic Children Play Here.'100 The Ministry of Transport favoured simple, uniform signs with the customary red circle to denote their mandatory nature but recognised that in the case of play streets...additional wording is desirable.' Most followed Salford's model with a smaller plaque beneath the circle carrying details of the hours of closure. Concerns that signs were being ignored led to a government decision to enlarge them in April 1957.101

\section{The Battle of Hardwick Street}

Applications for play streets were initiated by local authorities and confirmed by the Minister of Transport. Many councils only did this under pressure from local residents. Campaigns for play streets in post-war working-class districts were mostly led by women and suggest a growing antipathy towards cars which they considered illegitimate travellers through their streets rather than an accepted part of their own lives. Women's prominence is unsurprising given the emphasis on their responsibilities in pre-war debates about children's road safety. 'The mothers are more to blame than the children' Leeds City Coroner Sir William Clarke wearily told an inquest into the death of seven-year-old Martin Hart in 1928, they 'let these little toddlers go out of the house by themselves.'102

\footnotetext{
95 Herbert Alker Tripp, Road Traffic and its Control (London, 1950), 148.

96 TNA MT 95/30. Letter from Lt Col Pockard (RoSPA) to Mr H R Lintern, Ministry of Transport, no date [April 1947].

${ }^{97}$ Hansard, HC, vol. 302 cc.1543-614 (3 June 1935); TNA MT 95/30 Memo 17 April 1947.

98 Guardian, 13 September 1950.

99 TNA MEPO 2/7803. Press cutting from The World's Carriers, 15 August 1932. For more designs, see TNA MT 95/30.

100 TNA MEPO 2/7803.

101 Hansard, HC, vol. 313 c. 1755 (24 June 1936).

102 Yorkshire Evening Post, 3 April 1928.
} 
Statistics for accidents to pedestrians reported to Parliament in 1937 singled out those to 'children under seven unaccompanied or inadequately supervised', suggesting a level of maternal culpability. ${ }^{103}$ Along with apportioning blame, some commentators recognised women's ability to become key promoters of road safety. Hore-Belisha appealed to women to help him 'check road slaughter' by warning their husbands and children whenever they left home. ${ }^{104}$ Others acknowledged how traffic impacted on the patterns of working-class women's lives. Major Godfrey noted the 'heavy burden' walking children to school placed on 'the average working-class woman who has all the household duties to discharge,' and play streets' Parliamentary advocates described the 'haunting dread' and 'constant anxiety' of mothers 'when their children are playing in the street.'105

Post-war road safety discussions increased the focus on women's responsibilities. ${ }^{106}$ In 1951 the Children's Safety Crusade Trust, the Economic Research Council and the National Federation of Women's Institutes combined to study children's behaviour in traffic, explaining that 'the women of Britain can exert a strong and enduring influence upon public opinion' in this area. ${ }^{107} \mathrm{In}$ 1968 when officials at the Road Research Laboratory looked to reduce the 'high level' of accidents to young children they intended to consider parents' attitudes but commissioned a survey of mothers. ${ }^{108}$ As well as failing to protect their children from accidents, mothers were now blamed for causing them. One study in the British Medical Journal added 'maternal preoccupation' to the environmental factors such as lack of play facilities putting children at risk of road accidents. ${ }^{109}$ This approach was developed in later work, most notably in a study by psychologist Lindy Burton, which cited maternal stress and the early cessation of breast-feeding as triggers rendering children more 'vulnerable' to road accidents. ${ }^{110}$

Sadler's enquiry for the Road Research Laboratory found that although mothers accepted the 'main responsibility for teaching children road safety,' 'between a third and a half' of three to eight year olds still included 'the street among their usual play places.' 111 Nonetheless, many working-class women rejected suggestions of culpability with their demands for play streets revealing deep concerns over children's safety. Some of the most prominent demonstrations for play streets were in 1950s Liverpool where the local council opposed calls to adopt Salford's scheme in the 1930s and was slow to use its

\footnotetext{
103 Hansard, HC, vol. 330 cc. 387-9 (8 December 1937).

104 Daily Mirror, 16 July 1934.

105 Godfrey, Road Sense, op cit., 45; Hansard, HC, vol. 330 cc. 770-1 (10 December 1937).

106 See Thomson, op cit., 149.

107 Economic Research Council, The Child on the Road, (London, 1951).

108 TNA RG 40/466, H. Taylor, Road Research Laboratory to L. Moss, Central Office of Information, 18 September 1968; W.W. Scott, Minister of Transport, to Dr. Sheppard, Road Research Laboratory, 7 February 1969. Judy Sadler, Children and Road Safety: A Survey Amongst Mothers. (London, 1969).

${ }^{109}$ E. Maurice Backett and A. M. Johnston, 'Social patterns of road accidents to children: some characteristics of vulnerable families', British Medical Journal 1, 5119 (Feb. 14, 1959), 409-413. 110 Lindy Burton, Vulnerable Children (London, 1968), 8, 259.

111 Sadler, op. cit.
} 
powers under the 1938 Act. ${ }^{112}$ Everton's Labour MP Bertie Kirby, a supporter of the Act, voiced concern over Liverpool's lack of applications for play in Parliament in 1939.113 After the war the question re-emerged amid significant grass roots pressure. In 1947, 300 mothers and 200 children from around Great Howard Street petitioned their local councillor for play streets. Liverpool's first 12 play streets were opened within a year. There were 74 play streets by 1956 , with a further 23 applications pending, but progress was still too slow for some residents. ${ }^{114}$ A group of mothers from Hardwick Street took matters into their own hands, acting collectively to exercise control over their immediate environment and make it safe for their children, positioning themselves against what they saw as an invading enemy of anonymous motorists with no legitimate neighbourhood connection.

Hardwick Street (demolished in the late 1960s to make way for the new Royal Liverpool Hospital) was a narrow street of tall terraced houses close to the city centre that linked the busy junction at the end of Pembroke Place to Prescot Road, one of Liverpool's main arterial roads. It was situated in Low Hill ward, a district with 'few open spaces...aside from bomb-sites' and no parks close enough for children to visit unaccompanied. ${ }^{115}$ As post-war traffic grew, Hardwick Street became a regular 'cut through' for motorists seeking a quicker route to or from the city centre. In the autumn of 1956, mothers were disturbed by a spate of injuries to their children. Nine traffic accidents occurred in the first weeks of October with two on consecutive days. ${ }^{116}$ When Jennifer Jones was hit on 10 October the women decided to take action. ${ }^{117}$ On 11 October between fifty and sixty mothers blocked the street with their dustbins. No cars could pass until police and corporation workmen moved the bins. The next day, Friday, a crowd of around 300 women set up what was described as a 'Maginot Line' of babies in prams at the end of the school day. ${ }^{118}$ They returned at 11.30 next morning, just before the Saturday rush hour. When publicity surrounding the protest caused many cars to avoid the area the women suspended their campaign for a week while their demands were considered. Mrs M. J. Powell, a local socialist councillor, offered to put a motion to the next Council meeting in November. The demonstration's leaders demanded more immediate action so Powell wrote to the Watch Committee who discussed the matter on 16 October making a 'snap decision to close the road to traffic from the Crown Street end pending a decision on its future as a play street', which the women claimed as a victory. 119

The Hardwick Street demonstrations centred on women's view of the appropriate use of a street they considered a communal social space rather than

\footnotetext{
112 Guardian, 5 March 1931.

113 Hansard, HC, vol. 345 cc. 1279-80 (22 March 1939).

${ }^{114}$ Liverpool Echo, 5 October 1956.

115 Charles Vereker and John Baron Mays, Urban Redevelopment and Social Change (Liverpool, 1961) 72

116 The Times, 13 October 1956; Liverpool Echo, 13 October 1956; Liverpool Daily Post (subsequently LDP) 13 October 1956.

117 LDP, 12, 13 October 1956.

118 Ibid, 13 October 1956.

${ }^{119}$ Ibid, 17 October 1956.
} 
somewhere for the efficient movement of traffic around the wider city. Local and national press reports confirmed that women were fighting in defence of community and family, referring to 'The Battle of Hardwick Street', 'Barricade of Babies', 'victory' and 'defeat.'120 The women used their street to display their demands, chalking 'make Hardwick Street a play street' along its length. ${ }^{121}$ Contemporary photographs suggest that car ownership in Hardwick Street was non-existent, and protesters made no reference to parking in the street, or driving by residents. ${ }^{122}$ Accidents were blamed on the unknown motorists 'using [Hardwick Street] as a short cut between two main roads' as they commuted to and from work. ${ }^{123}$ No motorists were quoted in press reports and women made careful use of local and national media attention - including a television news feature - to explain how traffic threatened their habitual patterns of daily life. Motherhood - real or potential - underpinned women's justification for their protest and they invoked maternal- or matriarchal - identities to legitimise their activism. ${ }^{124}$ Mrs Quinn, a grandmother, revealed the community's collective attitude towards its '90 or 100 children,' describing the street as 'the only playground our kids have.' Through invoking motherhood women suggested that traffic threatened their traditional domestic and community roles. Mrs Alice Bowey, a mother of eleven (including one accident victim) showed how removing street sociability exacerbated the pressures of overcrowded housing asking 'How can a mother keep toddlers from going out into the street, the only playground they know?' 125 Mothers could no longer concentrate on housework, it was said, but must 'sit on the doorstep all day watching the children.'126 Mothers from adjoining streets shared the sense of collectivism. Spokeswoman Mrs Jane Young, a 'mother of three', explained how 'Every housewife in this street and in the side streets is acting as one. When the police...asked us who owned the bins not one of us replied.'127 Gendering their protest also allowed the women to minimize official reprisals. On the Saturday, when 'their men [were] at home' but 'were not seen in the street,' Mrs Young explained their barricade was 'woman's work... [the police] might hit the men, but they will not hit the women and children' while another protester pointed to the line of babies in prams who had replaced the dustbins and added 'let anybody try to take them away.'128

\footnotetext{
120 Liverpool Echo, LDP, Guardian, 13 October 1956.

${ }^{121}$ LDP, 12 October 1956.

122 This confirms Selina Todd's reinterpretation of Vereker and Mays' 1963 survey of the district where a 'small minority' of residents owned cars. See Selina Todd, 'Affluence, Class and Crown Street: Reinvestigating the Post-War Working Class', Contemporary British History 22:4 (2008), 501-518.

123 The Times, 13 October 1956.

124 On this point see Nancy Naples 'Introduction' in Naples, ed., Community Activism and Feminist Politics (London, 1998) 3 which notes how women who did not have children 'described their activism on behalf of their communities as a form of community caretaking.' Susan Stall and Randy Stoecker similarly considered the importance of motherhood to interpreting women's political activism in Stall and Stocker, 'Community organising or organizing community? Gender and the crafts of empowerment', Gender and Society 12, 6 (1998) 729-256 especially 749-50. 125 Liverpool Echo, 13 October 1956; LDP, 12 October 1956.

${ }^{126}$ LDP, 12 October 1956.

127 Guardian, 13 October 1956; Liverpool Echo, 13 October 1956.

128 Liverpool Echo, 13 October 1956; Guardian, 13 October 1956.
} 
In attempting to diffuse the situation the local authorities simultaneously asserted their right to define the purpose of street space. Initial police responses were muted. Some traffic was diverted, and the demonstration was allowed to continue but this changed when press attention brought 'high-ranking officers' including a Chief Superintendent from an adjacent division to take control of the situation. Protestors were warned to 'stay on the pavement or else you will be locked up' and told that they were going 'too far'. ${ }^{129}$ Whereas the women sought to preserve the street's communal and sociable functions, the police emphasized its purpose as a thoroughfare for traffic. "There has been no complete closure of the street', one officer told the Echo reporter, 'we have not the right to close it.'130 Elected representatives were unwilling to give the women total support. Local Labour MP Bessie Braddock signed their petition but urged them to stop. 'She said we would get ourselves into trouble and tried to talk us out of doing it', said Mrs Bowey, while Mrs Young added 'we didn't take a scrap of notice...We said that if women like ourselves had not fought years ago for a vote, she and other women would not be in Parliament.'131 Braddock's mother, Mary Bamber, had been a prominent Liverpool suffragist, a fact that she often invoked to legitimise her own political activity; she withdrew from the debate at this point. ${ }^{132}$ Most councillors were lukewarm. Joseph Norton, Conservative councillor for a suburban ward several miles away, visited the demonstration and expressed some sympathy, but suggested the city had wider needs. Norton suggested that a one-way street might be possible, but warned that 'there must be a great many streets in exactly the same position' and that altering them would 'interfere with the flow of traffic.'133 Preserving efficient movement through urban sidestreets was more important to the authorities than maintaining a safe space for women and children outside their own front doors.

The protests had some success. Hardwick Street never became a play street but did become a one-way street, excluding cut-through drivers for its remaining life. ${ }^{134}$ Women continued to demonstrate against traffic into the 1960s. Rooting their protests in their communities, they sought to protect and maintain their own spaces of sociability against what they perceived as the illegitimate use of residential sidestreets by non-resident motorists. ${ }^{135}$ Later protests in Liverpool included two against increased traffic from diversions during the building of the new Mersey Tunnel, and one against match-day parking outside Anfield stadium. ${ }^{136}$ Women blocked Bridge Street in Ellesmere Port in protest against motorists driving 'to the car park of the public house.' Further demonstrations for new play streets occurred throughout England as in Hackney in 1968 when Mrs Irene Lane's organization of local women and children secured the re-designation of their street. ${ }^{137}$ Women also fought to defend existing play

\footnotetext{
129 Liverpool Echo, 13 October 1956.

130 Ibid.

${ }^{131}$ LDP, 13 October 1956.

132 See Jack Braddock and Bessie Braddock, The Braddocks, (London 1963), 12.

133 Liverpool Echo, 13 October 1956.

134 The Times, 17 October 1956.

135 For a useful discussion of the spatial dimensions of women's community activism see Stall and Stoecker, 'Community organizing or organizing community?'.

136 Guardian, 25 April 1968, 10 September 1969.

137 Daily Mail, 29 August 1968.
} 
streets. After a car in a Bethnal Green playstreet hit six-year-old Alibi Monaf, 'children and angry mothers' surrounded the vehicle, climbing on the roof and banging on its windows. ${ }^{138}$ When 'Sunday morning drivers heading for the market' ignored play street signs in Montclare Street, Shoreditch, Jean Daley brought out her radiogram, blocking the street with dancing children who banged on the roofs of cars trying to get through. ${ }^{139}$ These protests again underlined the predominantly feminine character of post-war urban street sociability. While men were largely absent women legitimised their activism through invoking maternal roles, involving babies and children and using prams as barricades. ${ }^{140}$ When larger political groups attempted to connect to these campaigns it was still local women who led. Members of both the Young Communist League and the Vietnam Solidarity Campaign had spearheaded attempts to open up the private square of Powis Gardens to children of local North Kensington residents but it was only when two children were hurt in road accidents that 600 local mothers led a march to the Town Hall that forced the council to act. ${ }^{141}$ Defining - and defending - street sociability was very much women's business.

Women led play street campaigns in other ways. The files of Liverpool's Development and Planning Committee (which submitted orders for play streets to Whitehall) show female residents initiating requests. Many were mothers. Some hoped that achieving play street status would promote more tolerant attitudes recognising children's right to play in the street. Mrs. Hardman from Priory Road complained that her children were 'told to move from our own front door.'142 Others feared the encroachment of local businesses on the streets around their homes. As John Urry and others have noted, one early by product of rising automobility was a growing separation of workplace and home. ${ }^{143}$ Pooley and Turnbull's research on the journey to work in mid-twentieth century Britain found 'commuting by car becoming the most common means of travelling to work by the 1960s.' 144 More affluent workers could drive to work, offering them a greater choice of job than those reliant on public transport or walking. This, combined with using cars to retain older workplace traditions such as going home for lunch, produced three work-day peaks of traffic - morning, evening and mid-day - which co-incided with school hours raising traffic levels precisely when more children were on the streets. ${ }^{145}$ Mothers resented the invasion of drivers with - to their eyes - no legitimate business in their streets, and saw play street orders as the best means to preserve them as a safe social space for themselves and their children. Mrs. Hunt from Woodchurch Road complained to the committee about the impact of 'a number of cars and vans etc. parked in the

\footnotetext{
138 Ibid., 23 August 1968; Daily Mirror, 22 August 1968.

${ }^{139}$ Daily Express, 26 Aug 1962.

140 In Hull, prams and dustbins were again used as barricades (Guardian 8 July 1966), in Liverpool, Cllr Doreen Jones was fined $£ 5$ for obstruction after helping women block Dale Street with prams (Guardian 27 October 1971).

141 Jan O'Malley, The Politics of Community Action (London 1977) 83-4.

142 Liverpool Record Office (subsequently LRO) 352/Min/Dev/1, Development and Planning Committee Minutes 18 October 1962.

143 John Urry, 'The "System" of Automobility', Theory, Culture and Society, 21:5 (2004) 28.

144 C. G. Pooley \& J. Turbull, 'Coping with Congestion: Responses to Urban Problems in British Cities c. 1920-1960', Journal of Historical Geography, 31 (2005), 78-93, 79.

145 Gunn, 'People and the car', op. cit., 235.
} 
road way during the day.....belonging to employees of Littlewoods' warehouse' near her home while Mrs. Hennessey from Southbank Road said that children were at risk from cars driven by workers at the nearby Automatic Telephone Company who caused 'a rush of traffic' down the street 'at lunch time and at five o'clock'. ${ }^{146}$ A council investigation noted that the Southbank Road's usual daytime flow of around 20 vehicles per hour shot up to 250 per hour at the end of the Telephone Company's working day but the request was refused. ${ }^{147}$ Business traffic was becoming a priority.

Other objections sometimes came from elderly or childless residents who often referred to their age, or status when lodging appeals. C Butler, a resident of Rosebery Street, Liverpool, wrote that he was a 'totally disabled ex-serviceman' who would be 'forced to stay in the kitchen all the time with no break at all' if the order proceeded, due to the increased noise. In Hull, Mr. Scott from Hopwood Street mentioned his role as a shift worker who had to 'attend to the working of the docks...any time from midnight and all the time in the early morning.' 148 The Liverpool files nevertheless show that most residents supported play streets. Opposition could be quite easily diffused; Mr Scott withdrew his objection when reassured that a play street was not 'a playground fitted out with swings.'149

Business complaints were another matter. Godfrey's initial assessment of the Salford experiment stated that play streets should cause 'no interference with business', and that in their first seven years 'no complaint of inconvenience or annoyance' was received from firms. ${ }^{150}$ This changed as post-war businesses became more reliant on motor transport for moving supplies, goods and workers. Many play streets were close to small companies whose efficient working was increasingly dependent on road transport. Thus, while the problem of business-related traffic figured prominently in residents' requests for play streets, business owners were among their fiercest opponents. Coal merchants, tar distillers and coffin manufacturers led complaints over plans to expand play street provision in Hull in 1961.151 In 1963, objections to retaining play street status (granted in 1953) for Suffolk Street, Cheetham, were led by the owner of a wholesale fashion and leather goods firm on its corner who wanted 'the right to park his vehicles at the side entrance in Suffolk Street.'152 While mothers - who were generally carless - defended children's rights to play, business owners voiced the case for removing them from the streets. Hull District Credit and Check Traders' Association which represented over 170 firms complained that play streets would decrease members' efficiency as 'cars and cycles would have to be parked....and the visits [to householders] made on foot.' It urged the authorities to have 'consideration for the road user' and not 'prevent the genuine trader from going about his lawful business or from using the roads

\footnotetext{
146 LRO 352/Min/Dev/1, Development and Planning Committee Minutes 15 November 1962, 3 May 1963

147 Ibid., 3 May 1963.

148 TNA MT $137 / 6$.

149 TNA MT 137/6. Additional Play Streets Street Playgrounds (No. 2) Order, 1961.

150 Godfrey, op. cit., 69.

151 TNA MT 137/6. Various letters to Ministry of Transport, 17, 33 \& 22 February 1961.

152 Guardian, 28 August 1963.
} 
for the purpose for which they were made.' ${ }^{153}$ Authorities often prioritised the maintenance of efficient traffic flows to and from commercial premises despite the fact that play street legislation allowed for access during the closed hours. Decisions could be connected to safety and at least one application in Liverpool was rejected after police reported numerous 'commercial vehicles legitimately engaged' in visiting the street's various businesses. ${ }^{154}$ Such traffic could make play streets unworkable. Liverpool's Chief Constable reported to the Planning and Development Committee in November 1962 that many requested orders would prove ineffective as 'the major portion of the traffic [in inner-city streets] comprises vehicles of tradesmen and others calling at premises.' ${ }^{155} \mathrm{He}$ concluded that orders might be useful in streets with 'an appreciable amount of through traffic' but would exacerbate traffic problems by moving business parking onto major roads. ${ }^{156}$ When considering the best means of protecting business interests, the legitimacy of cars to be in sidestreets came to overtake that of women and children.

\section{Conclusions.}

Robert Colls' analysis of the decline of mid-century working-class streets' social functions noted that 'women lost, or ceded' them, defeated by a variety of competing interests including traffic. ${ }^{157}$ Looking at the history of urban play streets shows that women did not cede street sociability lightly but fought to preserve it against a range of different interest groups outside their neighbourhoods. Women's campaigns for play streets thus provide an important insight into different forms of female political activism rooted in their community networks. Such activities, Eleanor Jupp has argued, are frequently and easily - overlooked in accounts of activism which seek to 'scale up' local politics and 'broaden the scope...to wider contexts.'158 Unlike other forms of activism such as participation in local branches of political parties or organisations, play street protests were rarely connected to movements beyond the immediate locality. Yet in their form and content they represent a key example of women's 'implicit activism' undertaken on behalf of their communities, their families and themselves.

Despite their determination, however, by the late 1960s play streets were proving impossible to retain and most fell into obsolescence. Some were casualties of the last stages of post-war slum clearance that transformed urban landscapes, reducing terraces to a mere thirty per-cent of Britain's overall housing stock. ${ }^{159}$ As residents moved on, play streets such as Nicholas Square, Shoreditch were no longer at the centre of working-class communities but were lined with 'unoccupied and deserted houses.' ${ }^{160}$ Derelict play streets had a finite

\footnotetext{
153 TNA MT 137/6. Letter to Ministry of Transport, 21 January 1956.

${ }^{154}$ LRO 352/Min/Dev/1 Marlborough Street report, September 1962.

155 LRO 352/Min/Dev/4, Chief Constable to Planning and Buildings Sub Committee, 15 November 1962.

156 Ibid.

157 Colls, op. cit., 305.

158 Jupp op. cit., 3030.

159 Moran, 'Imagining', op cit., 180.

160 The Times, 31 December 1962.
} 
lifespan; a 'makeshift play street' in 'a sealed-off street due for redevelopment' in Notting Hill lasted only one summer before the builders moved in. ${ }^{161}$ Many relocated families viewed street play as undesirable on new estates with small front gardens and driveways. J. M. Mogey's study of Oxford's Barton Estate found that two thirds of its residents 'restricted their children to playing in the house or within the garden fence.'162 In Banbury, Margaret Stacey noticed these practices permeating surviving terraced streets where making children 'play in the ten-by-six foot yard' at the back of a house became a key means of distinguishing 'higher status' families from their 'rough' or less 'respectable' neighbours. ${ }^{163}$ Street play was no longer considered decent and indoor - or enclosed garden - play became an object of aspiration. ${ }^{164}$

Rising car ownership in the 1960s challenged the few surviving play streets. Plowden's figures show that when the Street Playgrounds Act was debated in September 1938, there were just under two million cars in use in Britain. By September 1969, there were over eleven million. ${ }^{165}$ This rise was not steady. Recent analysis identified 1955 - 70 as 'the period of most rapid growth in automobility', with a fivefold increase in cars. ${ }^{166}$ In 1951, eighty six per cent of households lacked regular access to a car, but by 1970 this dropped to below fifty per cent. 167 Cars were a necessity rather than a luxury, a shift that had a dramatic impact on the urban streetscape. The stationary car became a common sight on working-class streets, as Moran observed in Shirley Baker's later images of Salford streets, 'cluttered' with 'motor cars, albeit old and second-hand' that appeared 'parked incongruously' on the cobbles. ${ }^{168}$ Play streets' defenders became as concerned with parked as with moving cars. In 1968 Drummond Abernethy, Hon. Sec. of the International Playground Association, announced that play streets were 'disappearing', adding that it was 'psychologically wrong to allow children to play near parked cars.' ${ }^{169}$ Eight years later, Bishop Trevor Huddleston, founder of the charity Fair Play for Children, sadly observed that modern 'Britain preferred motor cars to children and showed it by cluttering up play streets with parked cars.' 170 Play street orders had secured working-class streets for children against the threat of moving traffic from outside of their district. They were less effective against cars parked by local residents as car ownership, aided by a buoyant second-hand market, spread across social classes.

A further significant factor in play streets' decline was a shift in the pattern of married women's employment. Between 1931 and 1971 the numbers of women working after marriage jumped from ten to just over fifty-one per

\footnotetext{
161 Ibid., 5 August 1968.

162 J. M. Mogey, Family and Neighbourhood (Oxford, 1956), 70.

163 Margaret Stacey, Tradition and Change: A Study of Banbury (Oxford, 1960) 108, 113.

164 Thomson, op. cit., 224.

165 Plowden, op. cit., 456.

166 Gunn, 'People and the car' op. cit., 236.

167 Office of National Statistics, Social Trends 40 (2010), 174.

168 Moran, 'Imagining', op cit., 178.

169 Guardian, 25 April 1968

170 The Times, 17 June 1976.
} 
cent. ${ }^{171}$ In Liverpool's Crown Street district (where Hardwick Street was located) they grew from six percent in 1956, the year of the protests, to fifteen percent in 1963.172 The growing affluence of two-income households brought a rise in the ownership of consumer goods, particularly cars. ${ }^{173}$ Viola Klein's investigation of married women workers in the early 1960s found that 'a car' was high on the list of the 'extras' that wives' incomes provided. ${ }^{174}$ Zweig's analysis of the spread of working-class car ownership in the same period explained how this both fuelled and facilitated a growth in married women workers as ' $[\mathrm{t}]$ he wife frequently pays for the car by going out to work and the car may enable her or make it easier for her to go out to work.' 175 Wives often worked part-time, particularly in working-class families where evening shifts starting at 5.30 or $6 \mathrm{pm}$ became 'the most popular' for part-time women workers. ${ }^{176}$ Working-class mothers who worked after their children had returned from school were more likely to only use their cars in the evening, leaving them parked on the streets during the day. They were also now away from home during the peak 'playing out' times, unable to join in with previous patterns of street sociability that the Hardwick Street protests had sought to retain.

All these factors fostered new fashions in play that did little to encourage play streets' survival into the twenty-first century. The shift towards indoor play from the 1970s, noted above, was matched by a rise in consumer goods aimed at children - computer games, bedroom televisions and electronic devices - easily affordable for working mothers that both responded to and encouraged this trend. Yet recently suggestions of change have emerged with a revival of interest in play streets, fuelled partly by concerns about childhood obesity and a renewed attention to the connection between children's learning and their ability to engage in outdoor play. Campaigners have again looked to New York, where the play street has continued since the 1920s, and argued for better planning to implement play streets into new estates in Britain. A recent National Lottery project has allowed for the reestablishment of play streets on an experimental basis. ${ }^{177}$ Organisations such as Playing Out, Street Play and London Play are actively seeking to reinstate outdoor play and play streets in British cities, albeit with more organised forms of adult supervision than the original pre and inter-war models. ${ }^{178}$ Such initiatives may yet provide the answer to reconciling the interests of parents, car owners and their children in an era when these groups are much less divisible than they were in the mid twentieth century. As they prompt fresh discussions over the usage of urban streets they

\footnotetext{
${ }^{171}$ Cited in Dolly Smith Wilson 'A new look at the affluent worker: The good working mother in post-war Britain', Twentieth Century British History 17, 2 (2006) 206-229, 209.

172 Todd, 'Crown Street' op. cit., 505.

173 Smith Wilson, op. cit., 217.

174 Viola Klein, Britain's Married Women Workers (London, 1965), 39.

175 Zweig, op. cit., 105.

176 Klein, op. cit., 129.

177 For details, see the timeline at http://www.londonplay.org.uk/document.php?document id=1333, accessed 7 July 2013. ${ }^{178}$ www.playingout.net accessed 24 January 2016; http://www.playengland.org.uk/streetplay accessed 24 January 2016; Alice Miles and Helen Rumbelow, 'How many adults does it take to let children play outside?' The Times, 4 August 2007.
} 
may also open the possibility for the re-emergence of social functions balanced against the interests of traffic. 